\title{
THE ROMA STUDENTS' PERCEPTION OF THE IMPORTANCE OF EDUCATION
}

\author{
Goran Lapat, $M S c$ \\ The Faculty of Teacher Education, \\ University of Zagreb, Department in Čakovec (Croatia) \\ e-mail: goran.lapat@vus-ck.hr \\ Hrvoje Šlezak, MSc \\ Elementary school Kuršanec, Čakovec (Croatia) \\ e-mail: hrvoje.slezak@zg.t-com.hr
}

\begin{abstract}
The paper considers the effects of the education of the Roma in the Medimurje County. Although positive effects are present in many different aspects related to education of the Roma, one of the most important is certainly the change in the attitude of the Roma toward their own education. The comprehension of importance of the Roma children's education and the intention to base their future material incomes on the work and competences acquired by education are an important step forward in developing a collective awareness of the Roma community of the importance of education and a giant step towards a more efficient integration.
\end{abstract}

Key words: Bayash, Croatia, Education, Integration, Međimurje, Roma people

\section{Introduction}

The Croatian Roma community is made up of various ethnical groups. In the northern part of Croatia, in the Međimurje County, the dominant group is the one which speaks Ljimba d' bjash. This is an old Romanian dialect that the Roma people have acquired during their stay in the area of today's Romania (Novak Milić, 2007; Olujić and Radosavljević, 2007). They emigrated to Croatia during the last decades of the nineteenth century. They consider themselves members of the Bayash Roma ethnic group, according to the language they speak.

The Roma people belong to the ethnic group which is the least integrated in modern Croatian society. There are two main reasons for this. The first one is related to severe prejudices and stereotypical views of the local population. Its consequence is high social alienation (Hrvatić, 1996; Banovac and Boneta, 2006) and social and spatial segregation of the Roma community. The second one is related to the fact that Roma people are not inclined to easily change their way of living due to their tradition which plays a very important role in their lives. As pointed out by Štambuk (2000a), Roma 
have chosen social distance as a way of communicating with the non-Roma environment, which helped them preserve their uniqueness and resist the assimilation process. However, at the same time they are hindering, delaying and slowing down the process of integration into the Croatian society.

Many researchers into Roma issues agree that education is the best way to integrate the Roma community (Hrvatić, 2000; Šućur, 2000; Dragun, 2000). According to Stambuk, " insisting on the education and progress in this area is a long-term, expensive and difficult path, but in effect the only one that will bring results in the future, and so the only rational one" (Štambuk, 2000a, 204). However, education of Roma children is marked by many difficulties and problems. Roma pupils find themselves captured between obligatory school programmes with expected educational achievement and real possibilities and capabilities they possess. As Novak Milić points out $(2007,94)$, "Roma children start school without having gone through any kind of preschool education, they face a variety of novelties but also difficulties, the greatest of which being the lack of knowledge of the standard Croatian language or dialect of the area where they live. They are also faced with a new cultural environment and social habits, and often with new objects and phenomena". A huge problem is that Roma children also lack competence in their own language. This means that a Roma child at primary school starts to learn not only Croatian words, but also concepts that lie behind these words (Novak Milić 2007).

The existing Croatian educational system is not adapted to the requirements and particularities of the Roma ethnic community. It is necessary to develop and implement an educational model that would be tailored to the needs, capabilities and requirements of the Roma minority, taking into account any specific features such as language, tradition and a particular system of values. A possible model for the conceptualization of education of the Roma in Croatia, which takes into account all the particularities of the Roma and the current educational system is proposed by Hrvatić (2000). He also suggests that "because there is no specific curriculum and school forms within the regular school system (specific curricula, courses, textbooks, teaching in the Romani language...) for the Roma minority, as it is partly organized for other national minorities, the process of conceptualization has to be necessarily implemented in a gradual, measured, precise and time-dimensioned way, based on scientific facts, therefore pedagogically competent" (Hrvatić, 2000, 269). Given that "education is the fundamental source of all Roma social, cultural and economic adversity and the basis of a specific, identifiable marginal position of Roma" (Štambuk, 2000a, 205), there is a need to introduce a special model of education with the ultimate goal of successful integration of the Roma ethnic minority in the Croatian society. Until now, no steps have been made in the implementation of the proposed models of schooling of the Roma.

Given that education is a very important, but not the only problem of the Roma ethnic minority, in the development of models, various procedures and actions aimed at the successful integration of the Roma minority in the Croatian society, there is a need for a comprehensive, holistic approach (Posavec, 2000) at a interdisciplinary level to cover all aspects and problems of their integration. It is also necessary to take into account the different value system of the Roma culture because, as Sibley indicates, Roma are often "viewed negatively because they do not correspond to the ideas of social and spatial order which prevail in the larger society" (Sibley, 1992, 110). 
However, certain improvements in the education of the Roma in Croatia do have been made. This is partly a result of the existing measures taken to improve the integration of the Roma into the Croatian society. Education is certainly one of the most important components of the integration of the Roma minority and as such has an important place in the National Programme for the Roma and Action Plan for the Decade of Roma Inclusion (Croatian Government, 2003, 2008).

The paper presents results of the survey conducted on a sample of 104 Roma students between fifth and eighth grade in the Međimurje County on the views of their own education and evaluation of its importance. The aim is to determine to what extent the existing educational system has affected the change in the value system of the Roma community in terms of understanding and acceptance of education as an important element of future successful integration into Croatian society. A series of alternative and open-ended survey questions explored the Roma student's perceptions of the importance of education, presence or absence of incentives for education in their social environment, and expectations of the impact of education on their future life.

\section{Roma students' perception on their own education}

The first part of the survey is related to the Roma students' relation to their education. The question Do you like going to school was positively answered by the largest number of students (Fig. 1). Only 6 out of 104 students responded negatively to this question.

Despite numerous problems in their education and a very high degree of their failure, the majority of Roma students like going to school. This distribution of answers gives us the right to consider the school a place where Roma students can leave their closed social environment. Because of the extreme spatial segregation of Roma in Međimurje (Slezak, 2009), the school is the only meeting point with the majority culture and it offers the possibility of integrative relations. It is likely that for a certain number of students the school presents the only place of safety, protection, and for some individuals possibly the only place where they can get a warm meal. In any case, school offers Roma students a variety of reasons which influenced the presented distribution of responses.

The question Is it important to go to school was affirmatively answered by $100 \%$ of students (Fig. 2). This distribution of responses indicates that in principle all Roma children are aware of the importance of education. The impact of the existing educational system is manifested in the development of awareness of the importance of education. 
Fig. 1 Frequency of Roma students' answers to the question "Do you like going to school?"

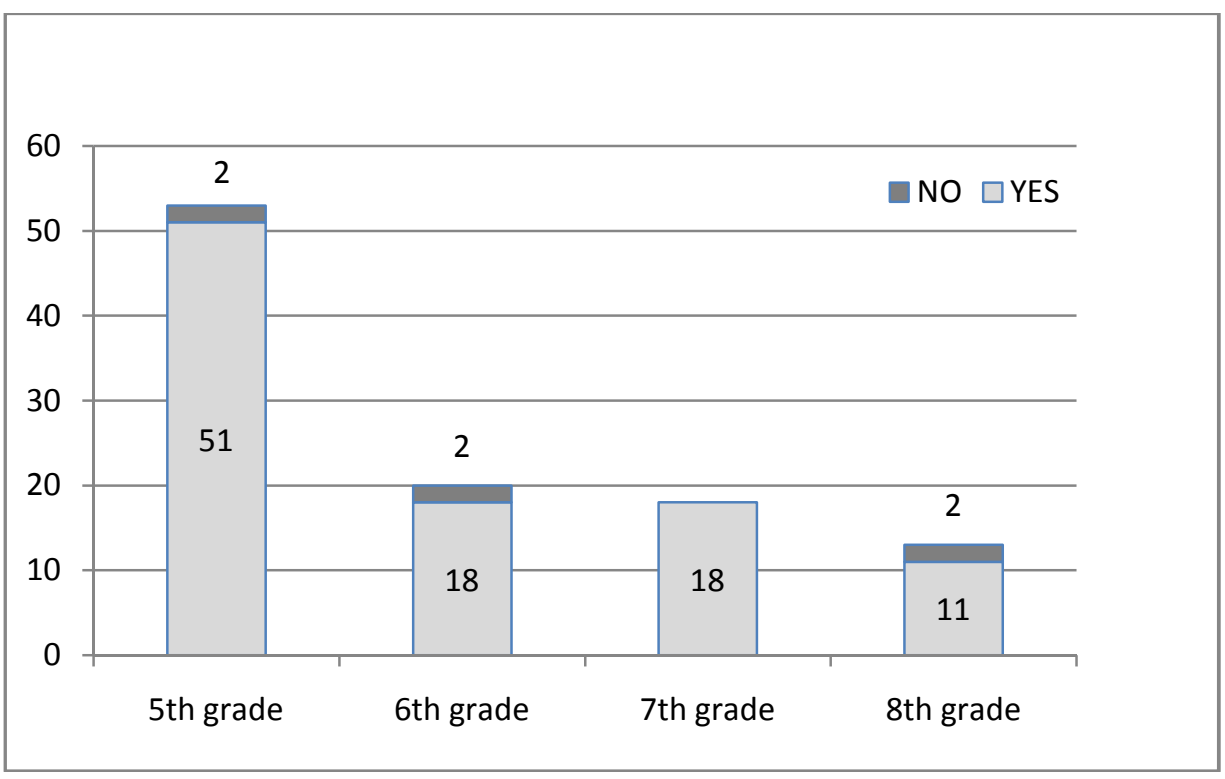

Although, in principle, they recognize the importance of education, Roma children in their social environment do not yet have role models that would confirm the relationship better education - a better life. Confirmation of this is evident from the distribution of responses to the question Would you go to school if it were not required (Fig. 3). As much as $35.6 \%$ of students answered negatively to this question. A little more than a third of the students would not attend the educational system in case they were not legally obligated. Despite the fact that they love going to school and generally know that it is important to go to school, a large proportion of students obviously do not see the appropriateness of their own schooling.

The problem of quality education and successful integration of the Roma minority in the Croatian society is connected to the fact that many Roma children are included in the educational system solely because of legal obligatoriness. The lack of empirical correlation between higher levels of education and a higher quality of life is a huge obstacle to education itself, and to the total integration of Roma. Although the current educational system has made a lot in terms of developing a collective awareness of the importance of Roma education, the other social institutions also need to put the theoretical understanding of the importance of education into practice. In other words, it is necessary to enable the Roma who have attained a certain level of education and have acquired a certain competence to find an adequately paid employment. 
Fig. 2 Frequency of Roma students' answers to the question "Is it important to go to school?"

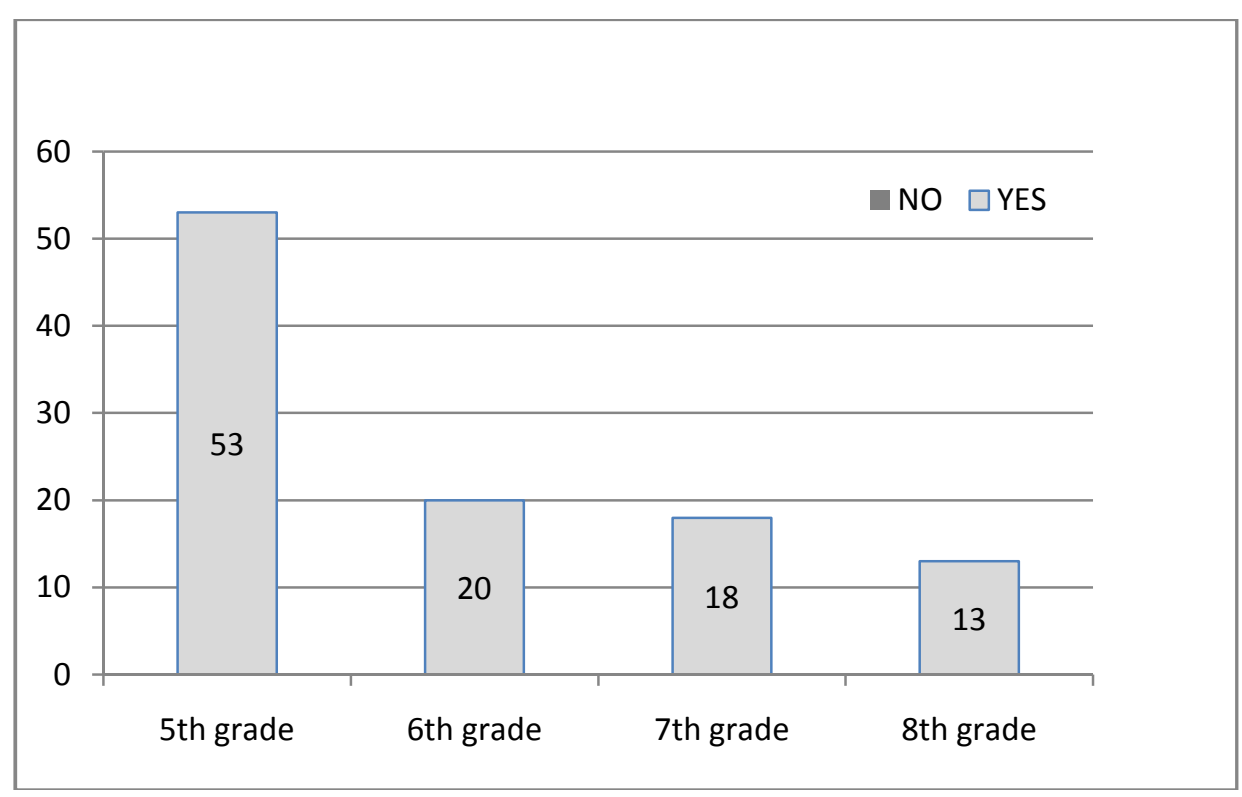

Fig. 3 Frequency of Roma students' answers to the question "Would you go to school if it were not required?"

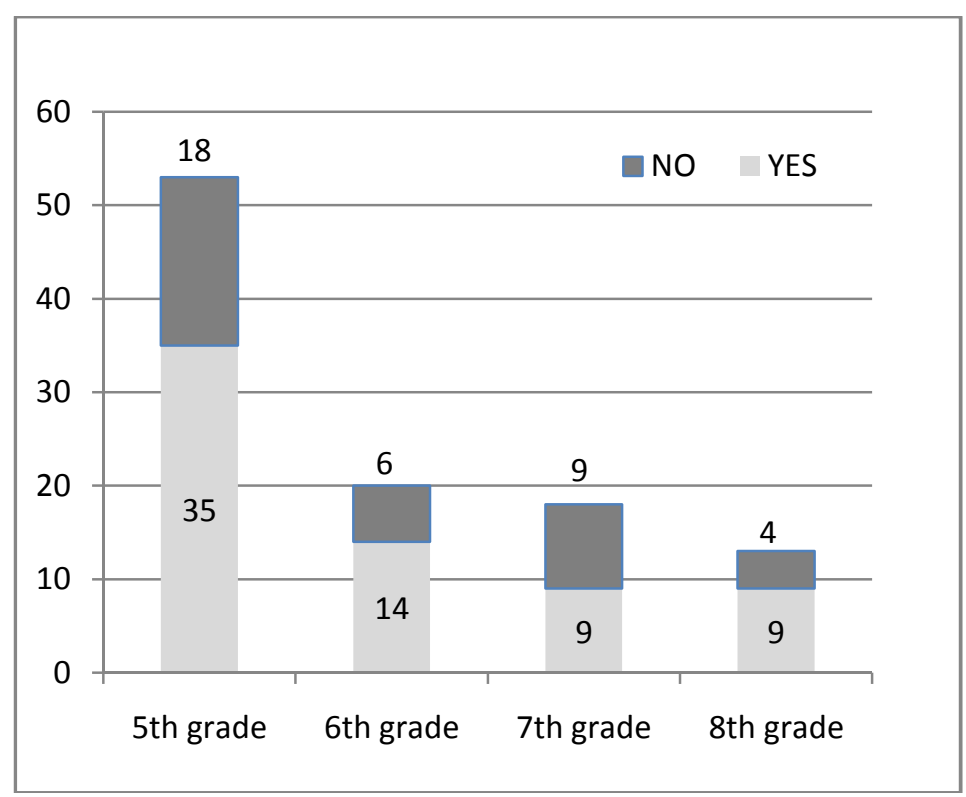

Only if there are examples in which education actually contributed to the quality of life of individuals of the Roma community, it is possible to expect substantial 
progress in education and the integration of the Roma. A little less responsible attitude toward education is evident from the responses on the last homework which was not done by $18.3 \%$ of students (Fig. 4). In a situation where many students do not see the appropriateness of their own education, it was actually encouraging that a very high percentage of Roma students (81.7\%) had done their last homework. This finding is even more significant when one takes into account the responses to the question What do you find difficult at school (Fig. 5).

Fig. 4 Frequency of Roma students' answers to the question "Have you done your last homework?"

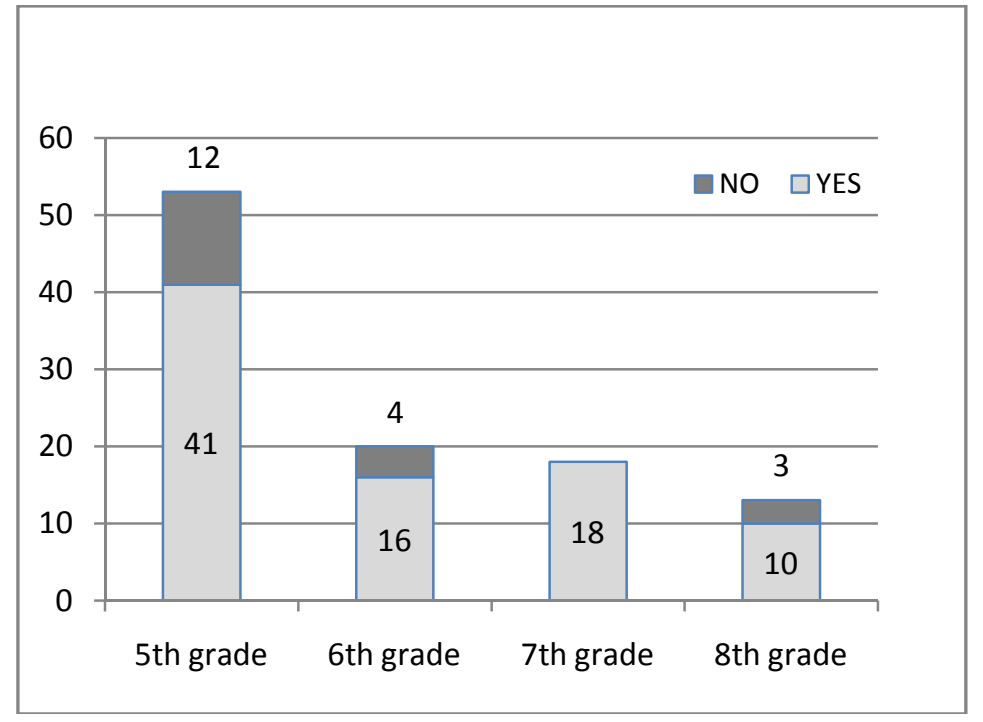

Although the largest number of students wrote that they did not find anything difficult at school, there were $29.8 \%$ of students who had trouble understanding the Croatian language. We should bear in mind that these were students between the fifth and eighth grades. It is obvious that the language barrier is a very significant barrier to the quality education of Roma in the upper grades of elementary school. As Roma in Međimurje are spatially separated from the majority of the population, in their social environment they interact solely in their mother tongue, the Bayash language. A number of students during their education successfully overcome the basics of the Croatian language, while for a number of students, almost one third of the elementary school upper graders, the Croatian language is still a major problem. This information is very important in the light of consideration of the justification of existence of ethnically segregated classes in some elementary schools in Međimurje. Although Roma formally achieved the status of a national minority to which the right to education in the native language is guaranteed, classes for Roma pupils are conducted in the language of the majority, Croatian. The reason for this lies in the fact that the Roma community in Croatia is composed of different ethnic groups that speak different languages. Another problem is that the Bayash language spoken by the Roma in Međimurje is not standardized, and it is only a colloquial language. Another problem is that currently 
there is only one member of the group of Bayash Roma from Međimurje with higher education and trained for educational work.

Fig. 5 Frequency of Roma students' answers to the question "What do you find difficult at school?"

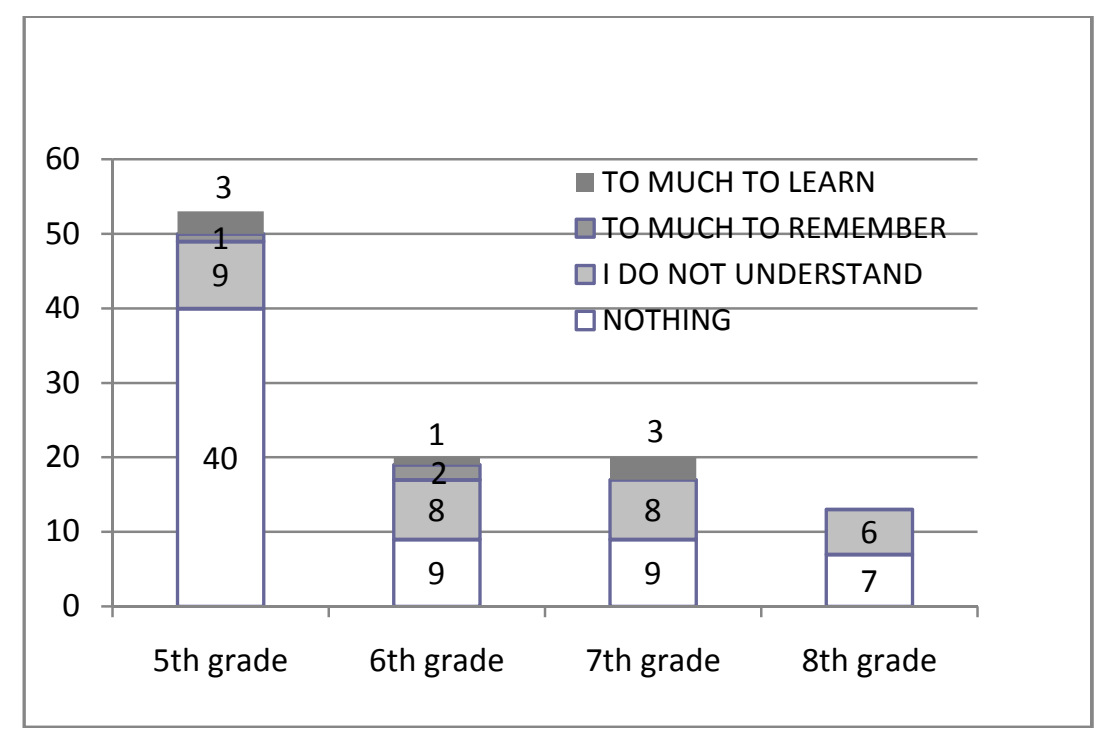

Learning is an important element for human happiness and satisfaction. $87.5 \%$ of all students surveyed, responded that after finishing their education, they would have a better life (Fig. 6). "Better" here stands for a higher standard of living, which should reduce the gap between the lifestyle of the Roma ethnic minority and the majority of the Croatian population. This information seems to be optimistic because Roma pupils do not have many examples in their surrounding that could support this hypothesis. Peculiarly, people who live "better" in Roma settlements do not have a "better" life because of their education. Sixth grade students were somewhat sceptical of the connection between education and the "better" life. Most of the surveyed Roma pupils $(66.6 \%)$ in sixth grade did not believe in "better" life, which would result from their education. Roma who have successfully completed primary school are almost all unemployed, even those who have completed secondary education for some simple jobs. Their unemployment discourages any belief in a "better" life after graduation.

Answers to previous questions should be closely linked with the answers to the question "Will you need knowledge acquired at school in your life?" Of course, Roma students saw the greatest benefit of reading, writing and comprehension. Mathematical knowledge is considered important in their lives, but only at the elementary level because it is associated with the need for calculation while shopping. For this purpose, the basic mathematical operations are sufficient. The students of the fifth, sixth and seventh grades mostly (98.9\%) responded that their knowledge acquired at school would be useful in their future lives. It is interesting to note that, though on a small sample, there were a certain number of eighth grade students who thought that they would not need their knowledge acquired at school in their life. Given that these students were 
about to complete their compulsory primary education, this response may have indicated that they had already decided to accept the traditional Roma way of life in which education plays no role, and as such it would not be necessary at all.

Fig. 6 Frequency of Roma students' answers to the question "Will you live better because of education?"

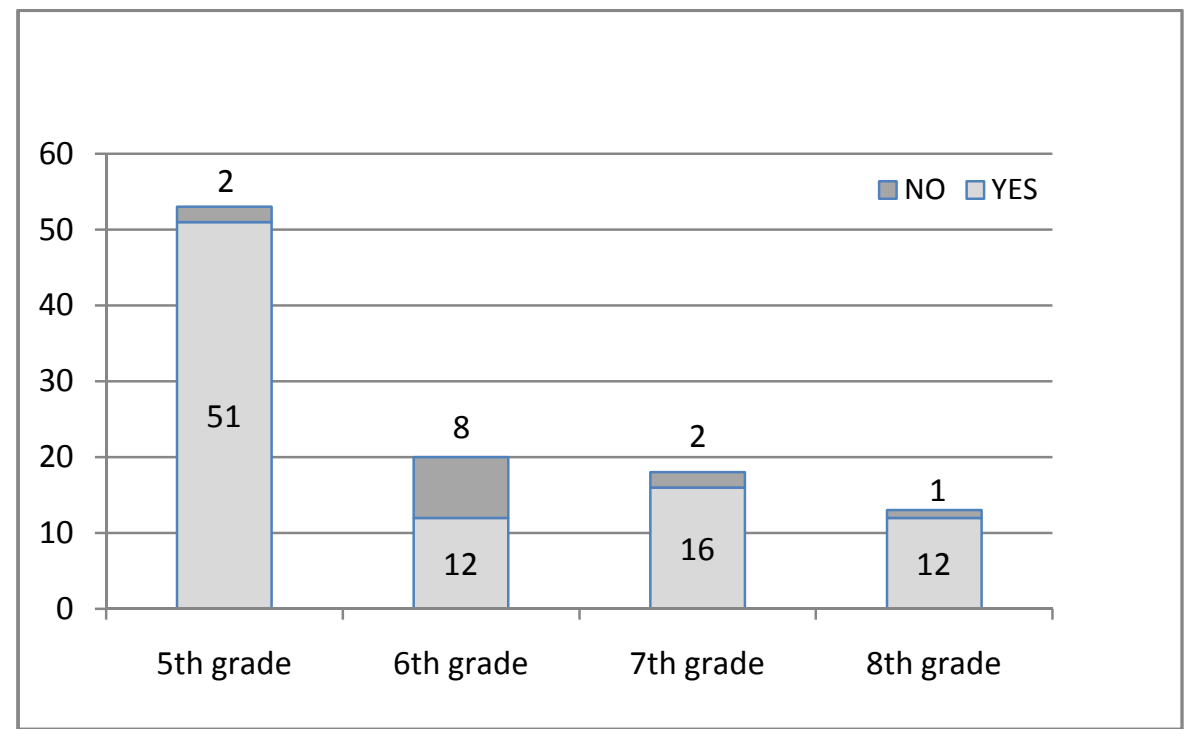

Figure 8 shows the answers to the question "What will be your source of income after finishing your education?" Students are aware that the money is the basic means necessary for life and that they can earn it with their own work. Even $82.7 \%$ of Roma pupils believed that in the future their own earnings would be sufficient for their life. This is a very important result on which we should base the development of measures for integrating the Roma. Change in the income structure of the Roma community is one of the main tasks that must be fulfilled for the purpose of equal Roma inclusion in the socio-economic life of the main society. The large number of Roma students who will base future incomes on their own work is an important educational attainment of the educational system. Certain number of students experienced that there were other ways that are very popular in the Roma community - the use of social assistance. Answers of seven students $(6.6 \%)$ that they would live on social assistance, tell us that they had no confidence in the possibility of employment. It is expected that social support, as a source of income, comes into force only after the impossibility of employment, but such responses, however, suggest indifference toward work. This means that they do not see the benefits of education. The answer "I do not know" chosen by $8.6 \%$ of the students was more acceptable. Students are aware of the benefits of education, but examples from their environment of the unemployed Roma who are educated for certain professions discourage them. The choice of farming and the collection of iron is a logical response of two students. In fact, most of the Roma in Međimurje make extra income in the gray economy, working for local agricultural producers, or by collecting secondary raw 
materials. The students realized that these were also the ways in which they could earn money in such environments.

The role of parents in the process of developing working habits, especially among school children, is to teach and encourage their children to develop these habits. The sooner the children adopt these working habits, the more likely it is that they would keep them and develop them later in life. A student is the most important factor of the whole process of education; he/she is the teacher's partner in their mutual work and the reason for the existence of the entire school system (Mijatovic, 2002). There are three important factors affecting student's achievement: student, teacher and parent. In this survey five students (4.8\%) stated that their parents did not encourage them to learn and meet school obligations, while $95.2 \%$ of them answered positively. It is certainly good that the students are encouraged by their parents to learn at home, as well as in school. It is therefore necessary to work systematically to raise awareness of the importance of education and improve educational competence of parents as support for the successful education of their children.

However, this encouragement by parents is not enough. Active participation of parents in the learning process and assistance in or control of writing their homework would increase the effect of education. Low educational level of their parents is the main obstacle to this. Despite all the difficulties and obstacles we can always find a solution to the cooperation of Roma parents and schools.

Although homework is an important component in the process of teaching and learning, the students find it very unpopular. Learners should be left the responsibility for their homework because they have to understand that it is their job and one of their priorities. Parents should provide an environment that will benefit homework writing, and in doing so, parents should not be too involved in the work itself, because the more responsibility they take, the less responsibility will be taken by the students. However, many of the Roma pupils, apart from not having a guaranteed employment, mostly do not know how to solve their homework independently. As much as $53.8 \%$ of students stated that no one helped them with homework, $28.8 \%$ responded that their brothers helped them, and only $17.3 \%$ received help of the parents. It is expected that their brothers usually helped them because the contents of the homework was "closer" to them than to their parents. However, in elementary schools in Međimurje attended by the Roma there are Roma assistants. A Roma assistant is a member of the Roma population with at least high school education whose job description is somewhat comparable to that of teaching assistants. One of the conditions is that they know Bayash language spoken by the Roma population in Međimurje. A Roma assistant usually serves as an interpreter because parents and children communicate in their own language which the teacher does not understand. However, apart from being an interpreter, they serve as a link between home and school and also help the students with homework. The fact that most of the students do not get help with their homework is upsetting because it does not mean that they write it independently, but have no one to ask for help. 
Fig. 7 Frequency of Roma students' answers to the question "Will you need knowledge acquired in school in your life?"

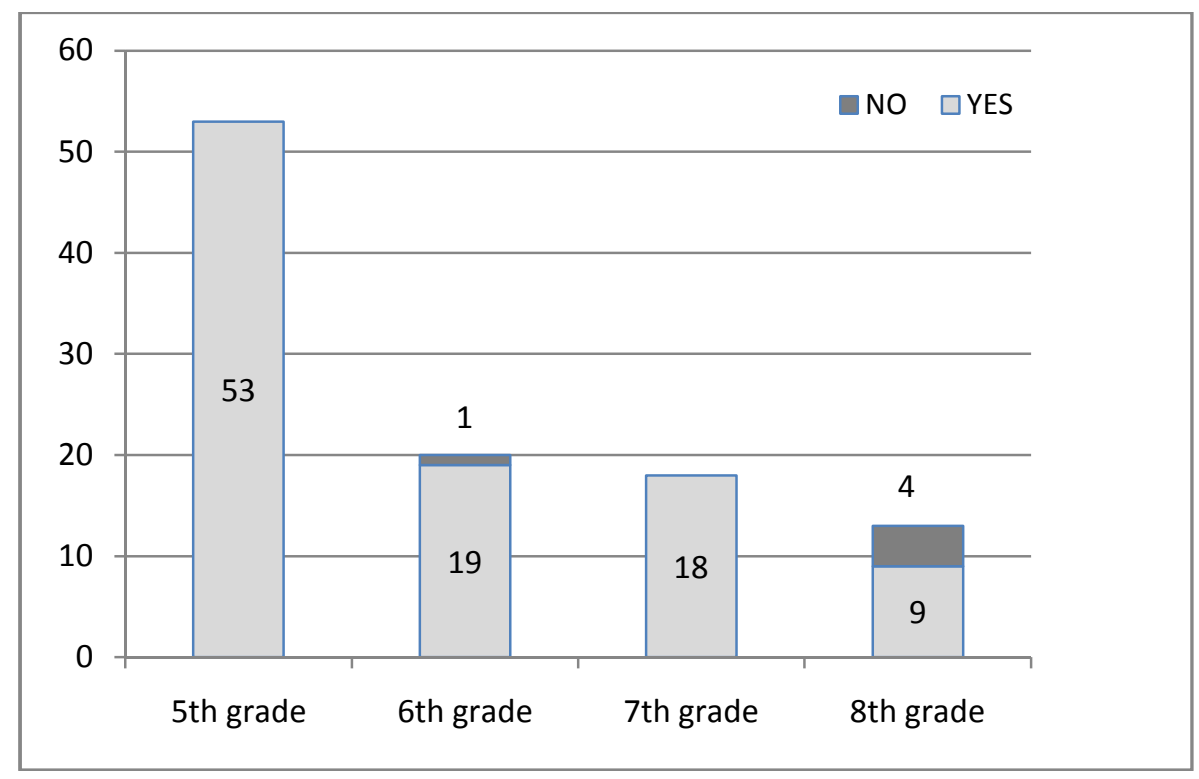

Fig. 8 Frequency of Roma students' answers to the question "What will be your source of income after finishing your education?"

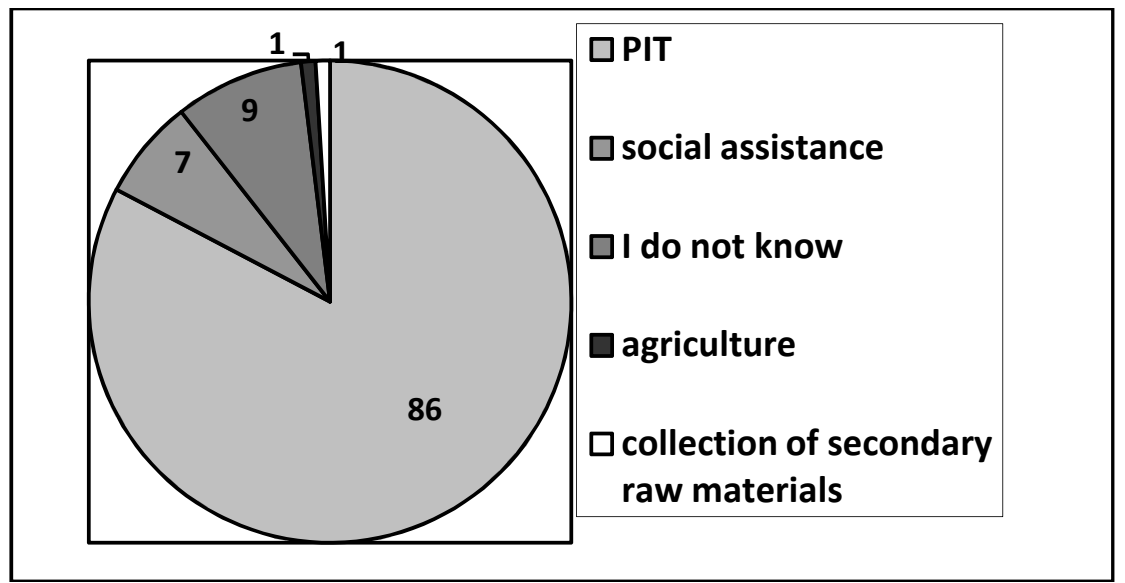


Fig. 9 Frequency of Roma students' answers to the question "Do your parents encourage you to learn and write homework?"

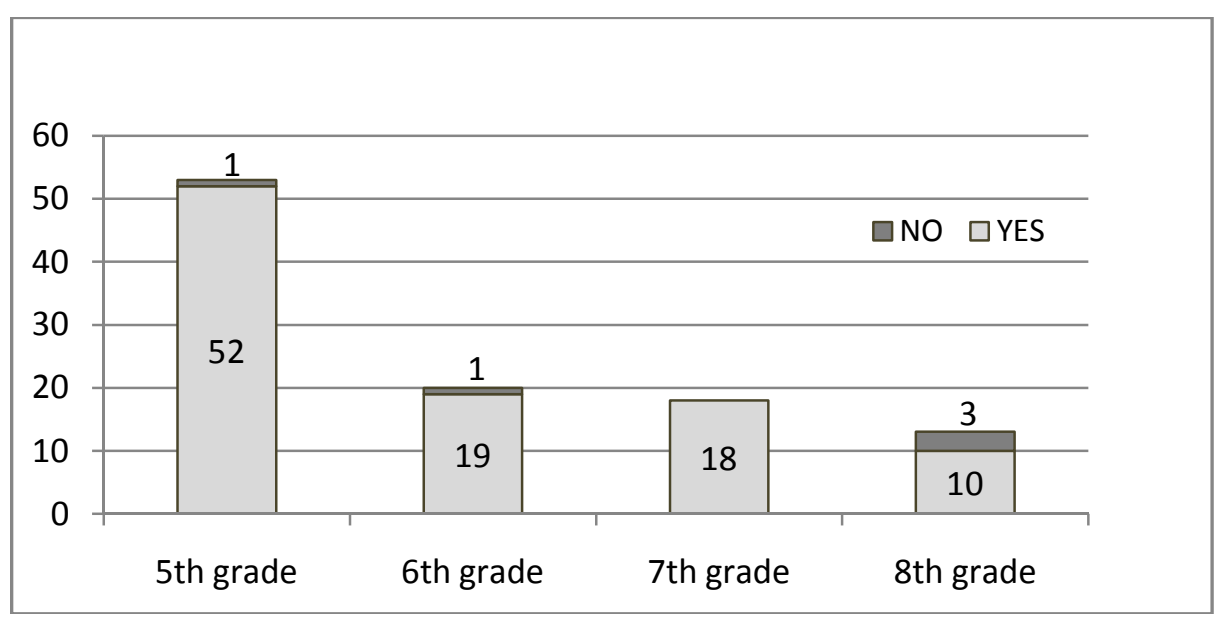

Fig. 10 Frequency of Roma students' answers to the question "Who helps you with learning and homework?"

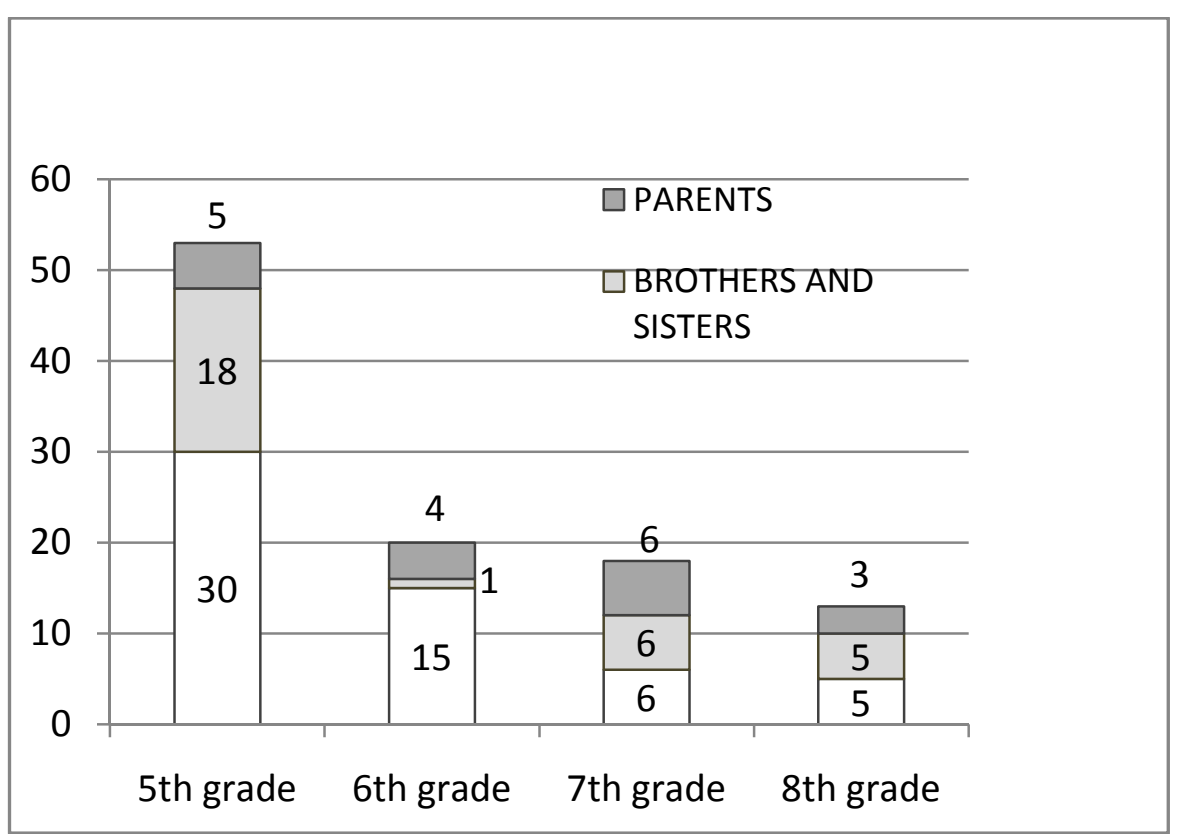




\section{Conclusion}

Work with Roma children raises special challenges for educators and teachers and requires specific professional competence. Educators and teachers are not prepared for these specific components during their training. These components imply knowledge of the Roma language (in the case of Medimurje the Bayash language) and culture of the Roma community, special flexibility in work, the art of practicing various forms of cooperation with parents. Rumbak (2007) argues that, sometimes, only a Roma teacher can adequately respond to the specific needs of the Roma children. Equality, which is provided by law, is not enough. All children have the same rights, including the Roma children. Economic opportunities, heritage and tradition obstacles the Roma children to be involved in the educational system as well as the others. To solve this problem, Roma parents should be educated. In their homes a diverse and stimulating environment should be created to enable child's optimal physical and psychomotor development, because such environment provides challenges for the child and raises standards of his/her performance. For these students, school has to become a place they recognize as a warm and safe environment with the long-term aim of raising the quality of their lives. The results point to a significant progress in understanding the importance of education for the Roma children. Although a certain part of the Roma pupils in principle accept the thesis of the importance of education as a prerequisite for a future quality of life, the importance of educational attainment should not lose its importance. Moreover, the educational system as such is not able to provide practical confirmation of the importance of education. With the aim of a successful integration of the Roma community in the predominantly Croatian society it is essential that the integration process started through the primary school system is continued in due time by the involvement of other institutions that will help the Roma community in Međimurje to obtain a higher number of individuals who will confirm that education actually contributes to the quality life.

\section{Bibliography}

Banovac, B., Boneta, Ž., 2006: Etnička distanca i socijalna (dez)integracija lokalnih zajednica, Revija za sociologiju, 37 (1-2), 21-46.

Dragun, M., 2000: Podrijetlo, mitologija i vjerovanja Roma, Društvena istraživanja 46-47, 317333.

Hrvatić, N., 1996: Romi u interkulturalnom okružju, Društvena istraživanja 25-26, 913-933.

Hrvatić, N., 2000: Odgoj i izobrazba Roma u Hrvatskoj, Društvena istraživanja 46-47, 267 290.

Rumbak, I., 2007: Strategija obrazovanja Roma u Republici Hrvatskoj. Zagreb: Humanitarna organizacija Roma u Hrvatskoj. Zagreb.

Mijatović, A., 2002: Obrazovna revolucija i promjene hrvatskog školstva, Hrvatski zemljopis

Novak Milić, J., 2007: Hrvatski i romski u prvim godinama školovanja, u Drugi jezik hrvatski (ur.Cvikić,L.), Profil, Zagreb, 92-97. 
Olujić, I., Radosavljević, P., 2007: Jezik Roma Bajaša, u Drugi jezik hrvatski (ur. Cvikić, L.), Profil, Zagreb, 102-110.

Posavec, K., 2000: Sociokulturna obilježja i položaj Roma u Europi - od izgona do integracije, Društvena istraživanja 46-47, 229 - 250.

Sibley, D., 1992: Outsiders in society and space, u Inventing Places: Studies in Cultural Geography, (ur. Anderson, K; Gale, F), Longman Cheshire, Melbourne, 107 -122.

Šlezak, H., 2009: Prostorna segregacija romske stanovništva u Međimurskoj županiji, Hrvatski geografski glasnik 71 (2), $65-81$.

Štambuk, M., 2000: Romi u društvenom prostoru Hrvatske, Društvena istraživanja 46-47, 197 -210 .

Šućur, Z., 2000: Romi kao marginalna skupina, Društvena istraživanja 46-47, 211 - 227.

Vlada Republike Hrvatske, 2003: Nacionalni program za Rome, http://www.umrh.hr/ Nacionalni\%20program\%20za\%20Rome.pdf (11. 01. 2010.)

Vlada Republike Hrvatske, 2008: Akcijski plan Desetljeća za uključivanje Roma 2005.-2015. (11. 01. 2010.) http://www.vlada.hr/nacionalniprogramromi/content/blogcategory/14/30/ lang,hrvatski/

Metodički obzori 6(2011)1

Prethodno priopćenje

UDK: 376.7(497.5-35 Čakovec $=214.58)$

Primljeno: 13.7. 2010

\title{
PERCEPCIJA UČENIKA ROMA O VAŽNOSTI OBRAZOVANJA
}

\author{
mr. sc. Goran Lapat, \\ The Faculty of Teacher Education \\ of the University of Zagreb \\ Department in Čakovec Croatia \\ goran.lapat@vus-ck.hr \\ mr. sc. Hrvoje Šlezak, MSc \\ Elementary school Kuršanec, Čakovec Croatia \\ hrvoje.slezak@zg.t-com.hr
}

Sa žetak

Rad raspravlja o dosadašnjim učincima obrazovanja Roma na primjeru Međimurske županije. Iako su pozitivni učinci prisutni u više različitih aspekata vezanih uz obrazovanje Roma, među najvažnijim ističe se promjena odnosa Roma prema vlastitom obrazovanju. Shvaćanje važnosti obrazovanja kod romske djece i želja da im budući materijalni prihodi budu temeljeni na radu i kompetencijama stečenim obrazovanjem važan su pomak u razvoju kolektivne svijesti romske zajednice o važnosti obrazovanja i velik korak prema uspješnijoj integraciji.

Ključne riječi: Bajaši, Hrvatska, integracija, Medjimurje, obrazovanje, Romi 